\title{
The District Education Offices in Improving the Quality of Education Junior High School in Pedamaran District
}

\author{
Desy Hartini ${ }^{1 *}$, Bukman Lian $^{2}$, Syaiful Eddy ${ }^{2}$ \\ ${ }^{1}$ Pedamaran Senior High Schools \\ ${ }^{2}$ Universitas PGRI Palembang \\ ${ }^{*}$ Corresponding author. Email: rendialeks123@gmail.com
}

\begin{abstract}
This study aims to describe the strategic challenges and solutions in the face challenges in improving the quality of education junior high school in Pedamaran District. The qualitative approach was used in this research with interviews, documentation, and observation as data collecting techniques. The research results found that department of education has strategy to improve the quality of education junior high school in Pedamaran District has been good enough. Improving the quality of school can be described as being two challenges is structurally and culturally. First, freeing the students and teachers to find sources of additional learning. Second, controlling the students' absence, reproof or a real action, to bring the parents of students to school, home visit, the establishment of the budget as the need more urgent, and always it established cooperation with other sides parties.
\end{abstract}

Keywords: District Education Offices, Quality of Education, Junior High School

\section{INTRODUCTION}

Teachers who have good performance give hope and desire for all parties, especially the general public, where good teachers will produce schools trusted by the surrounding community in educating and teaching children about science and attitudes. The success of education can very much be obtained by the performance of teachers [1]. In principle, teachers have a high enough potential to be creative in order to improve their performance. However, the potential that teachers have to be creative in an effort to improve their performance does not always develop smoothly. This is found by various factors, such as teachers and/or teachers who have second jobs.

The District Education Office of Ogan Komering Ilir (OKI) is the Regional Education Office that carries out technical and educational affairs, such as interaction and regulation of teacher performance. However, the performance of the OKI District Education Office has not been optimal for improving performance. Teachers in districts in continuous development and development of teacher competencies (continuous professionalism development) through groups of deliberation teachers and teachers of deliberation subjects. The principal group only holds seminars, workshops, and training, so that teachers receive less guidance and development [2].
Problems that occur in this field need to be studied in depth so that efforts can be made by the central and district/city governments to improve and advance teacher performance in a better direction.

Besides, another problem is the lack of training and workshops held in the OKI district. The number of schools with the quality of teachers participating in training and workshop activities. Also, teachers who have received training and coaching are not doing their job well, so that their education does not improve significantly.

\section{METHODS}

The research method used in this research is qualitative research. This research is specifically designed to describe the social phenomena associated with improving the quality of junior secondary education in Pedamaran. Qualitative research is needed from the social research questions that use investigating based on social phenomena [3]. The informants in this study consisted of 31 people, including four school principals, 20 teachers and students from junior high schools state 1 and 2, junior high schools Kesatuan, and junior high schools 1 PGRI and six staff of the district education office Ogan Komering Ilir (OKI). We collected the data 
in this study using interviews, observation, and documentation.

\section{RESULTS AND DISCUSSION}

The education office's strategy to improve the quality of junior high school education in the sub-district of Pedamaran is carried out in accordance with the government's standards. The main problem in improving teacher performance is time management and financial issues. There is a positive relationship between teacher time management techniques and classroom performance. Effective time management can be seen from the teacher learning planning technique. So it is advisable to hold a teacher training program to improve teacher managerial and administrative activities [4]. Teachers will always develop by themselves according to the times and their existence continuously according to professionals. Teachers' professionalism will be easily obtained by teachers supported by the school management according to the conditions and situations where the school is a strong school of teachers to carry out their duties optimally.

The four schools studied, namely SMPN 1, SMPN 2, SMP Kesatuan, and SMP PGRI, generally do not have challenges that keep up with the times, where the challenges they face can still be handled properly. Research conducted by Dahlan et al [5] found that educational activities such as providing training and school remembrance culture aim to learn activities carried out by teachers following their goals and objectives. So, it is necessary to carry out training and a more modern school remembrance culture.

The efforts made by SMPN 1, SMPN 2, SMP Kesatuan, and SMP PGRI with the District Education Office are to free students and teachers to triangulate additional learning sources. Control student absences, warnings, or concrete actions, bring parents to school, home visits, determining the budget according to more urgent needs, and always cooperating with other parties. The benefit of home visits is to strengthening homeschool partnerships [6]. Home visits give more connection between children and their parents [7]. Besides, improving communication between children and their parents is better, so school gives good feedback [6].

In his study, school culture describes the working relationship between fellow teachers, teachers, and school principals, between teachers and other education personnel, and between those related in that environment as a form of conducive environment. A school culture that enables teacher empowerment and the influence of teacher empowerment [8]. In addition, training and workshops are expected for teachers to develop and be practical for school fees in the learning process to run well. If the teacher implements professional principles in carrying out their duties and functions, it will result in better performance as an educator. Training and workshop for junior high school students are needed because they give benefits to improve teacher professionalism [9].

The education office's strategy to improve junior high school education quality in the Pedamaran sub-district is good enough along with SMP 1, SMP 2, SMP Kesatuan, and SMP PGRI. The strategy to improve the quality of schools must be more comprehensive. The strategy for improving the quality of schools is also cultural in nature because schools always make innovations and implement the national education standards that have been set. Planning to improve the quality of schools in the four junior high schools is always improved in the medium term, namely the 2016/1017 to 2019/2020 academic year.

The school's quality can be described as a structural school and in terms of cultural challenges. The structure of government books is still less relevant, so teachers must have references. The cultural challenge is the students' heterogeneous condition: less, budgeting solely for school government funds, the development of social media, and technology. The government must be considered about the quality and condition of teachers that can give the effect to performance in the school [10].

\section{CONCLUSION}

The conclusion of this study is the efforts made by SMPN 1, SMPN 2, SMP Kesatuan and SMP PGR with the Regional Education Office are good enough and using cultural aspect.

\section{REFERENCES}

[1] Zamroni. (2013). Manajemen Pendidikan: suatu usaha meningkatkan mutu sekolah). Yogyakarta: Ombak.

[2] Zazin. (2016). Gerakan Menata Mutu Pendidikan: teori dan aplikasi. Yogyakarta: Ar-Ruzz Media.

[3] Ritchie, J., \& Ormston, R. (2003). The applications of qualitative methods to social research. Qualitative research practice: A guide for social science students and researchers, 24, 46.

[4] Khan, H. M. A., Farooqi, M. T. K., Khalil, A., \& Faisal, I. (2016). Exploring Relationship of Time Management with Teachers' Performance. Bulletin of Education and Research, 38(2), 249-263.

[5] Dahlan, D., Hasim, D., \& Hamdan, H. (2017). Pengaruh Manajemen Sumber Daya Manusia dan Budaya Organisasi Terhadap Kualitas Pelayanan Pada Kantor Kecamatan Tamalate Kota Makassar. Jurnal Ad'ministrare, 4(2), 69-75. 
[6] Meyer, J. A., \& Mann, M. B. (2006). Teachers' perceptions of the benefits of home visits for early elementary children. Early Childhood Education Journal, 34(1), 93-97.

[7] Lin, M., \& Bates, A. B. (2010). Home visits: How do they affect teachers' beliefs about teaching and diversity?. Early Childhood Education Journal, 38(3), 179-185.

[8] Balkar, B. (2015). Defining an empowering school culture (ESC): Teacher perceptions. Issues in Educational Research, 25(3), 205-224.

[9] Lai, H. J. (2010). Secondary school teachers' perceptions of interactive whiteboard training workshops: A case study from Taiwan. Australasian journal of educational technology, 26(4).

[10] Adedeji, S. O., \& Olaniyan, O. (2011). Improving the conditions of teachers and teaching in rural schools across African countries (pp. 1-89). Addis Ababa: UNESCO-IICBA. 